\title{
More than Just a "Motor": Recent Surprises from the Frontal Cortex
}

\author{
(1)Christian L. Ebbesen, ${ }^{1,2}$ Michele N. Insanally, ${ }^{1,2}$ Charles D. Kopec, ${ }^{3}{ }^{\oplus}$ Masayoshi Murakami, ${ }^{4}$ Akiko Saiki, ${ }^{5,6}$ \\ and ${ }^{-}$Jeffrey C. Erlich ${ }^{7,8,9}$ \\ ${ }^{1}$ Skirball Institute for Biomolecular Medicine, New York University School of Medicine, New York, New York 10016, ${ }^{2}$ Center for Neural Science, New York \\ University, New York, New York 10003, ${ }^{3}$ Princeton Neuroscience Institute, Princeton University, Princeton, New Jersey 08544, ${ }^{4}$ Department of \\ Neurophysiology, Division of Medicine, University of Yamanashi, Chuo, Yamanashi 409-3898, Japan, ${ }^{5}$ Institute of Biomedical and Health Sciences, \\ Hiroshima University, Hiroshima, 734-8553, Japan, ${ }^{6}$ Department of Neurobiology, Northwestern University, Evanston, Illinois 60208 , ${ }^{7} \mathrm{New}$ York \\ University Shanghai, Shanghai, China 200122, ${ }^{8}$ NYU-ECNU Institute for Brain and Cognitive Science at NYU Shanghai, Shanghai, China 200062, \\ and ${ }^{9}$ Shanghai Key Laboratory of Brain Functional Genomics (Ministry of Education), East China Normal University, Shanghai, China 200062
}

Motor and premotor cortices are crucial for the control of movements. However, we still know little about how these areas contribute to higher-order motor control, such as deciding which movements to make and when to make them. Here we focus on rodent studies and review recent findings, which suggest that_-in addition to motor control-neurons in motor cortices play a role in sensory integration, behavioral strategizing, working memory, and decision-making. We suggest that these seemingly disparate functions may subserve an evolutionarily conserved role in sensorimotor cognition and that further study of rodent motor cortices could make a major contribution to our understanding of the evolution and function of the mammalian frontal cortex.

Key words: motor control; active sensing; action selection; action timing; decision-making; frontal cortex

\section{Introduction}

Primate motor and premotor cortices are some of the most intensely studied structures in all of neuroscience. Despite our sizeable knowledge, several major conceptual questions remain open. For example, the classic controversy over whether motor cortex acts mainly as a musclelotopic map of the body, organizing low-level features of movements (e.g., force; Evarts, 1968; Asanuma, 1975) or mainly represents high-level movement kinematics (Fetz, 1992; Omrani et al., 2017) has recently been further complicated by the observation that motor cortex appears to be organized both somatotopically and according to behavioral categories (Graziano et al., 2002; Graziano, 2016). Second, it is still an open question whether population activity sums to generate motor output (Georgopoulos et al., 1982, 1986), or whether preparatory activity, for example (Tanji and Evarts, 1976) is better understood as acting to configure the state of a dynamical system (Shenoy et al., 2013). Third, in a sense, motor control is decisionmaking (Wolpert and Landy, 2012), but we still know little about

\footnotetext{
Received Aug. 1, 2018; revised Sept. 14, 2018; accepted Sept. 17, 2018.

This work was supported by The Novo Nordisk Foundation (C.L.E.); NYU Provost's Postdoctoral Fellowship and NIDCD K99/R00 Pathway to Independence Award DC015543-01A1 (M.N.I.); F32 MH098572/MH/NIMH NIH HHS/ USA, and Howard Hughes Medical Institute/USA (C.D.K.); Uehara Memorial Foundation, Fundação Bial 127/08 and Fundação para a Ciência e a Tecnologia SFRH/BPD/46314/2008 (M.M.); JSPS KAKENHI Grant Number JP18J01678 and JP17K12703 (A.S.); and Program of Shanghai Academic/Technology Research Leader 15XD1503000 and Science and Technology Commission of Shanghai Municipality 15JC1400104 (J.C.E.).

The authors declare no competing financial interests.

Correspondence should be addressed to Dr. Christian Ebbesen, New York University, 540 First Avenue, New York, NY 10016. E-mail: christian.ebbesen@nyumc.org.

https://doi.org/10.1523/JNEUROSCl.1671-18.2018

Copyright $\odot 2018$ the authors $\quad 0270-6474 / 18 / 389402-12 \$ 15.00 / 0$
}

how motor cortices contribute to actually deciding how and when to act (or not to act; Ebbesen and Brecht, 2017), beyond simply managing the execution of the selected motor plans (Gold and Shadlen, 2007; Thura and Cisek, 2014; Remington et al., 2018). Finally, the discovery of mirror neuron responses in premotor (di Pellegrino et al., 1992), but also in proper M1 (Tkach et al., 2007; Dushanova and Donoghue, 2010) and corticospinal M1 neurons (Vigneswaran et al., 2013; Kraskov et al., 2014) raises intriguing questions about how motor cortices contribute to motor imagery, action understanding, social meta-cognition and cognition more generally (Kilner and Lemon, 2013).

A comparative study of forebrain motor control in rodents in addition to primates (and other species; Ocaña et al., 2015), could be a powerful way to advance our understanding of the evolution and function of the mammalian frontal cortex. In recent years, there has been massive advances in tools for monitoring and manipulating neural activity of awake, behaving rodents with cellular and subcellular resolution, beyond what is currently practical in primates. For example, there are currently abundantly available transgenic lines and viral tools (Heldt and Ressler, 2009; Witten et al., 2011; Harris et al., 2014), optogenetics (Deisseroth, 2015; Kim et al., 2017), DREADDs (Whissell et al., 2016), in vivo multiphoton imaging of various sensors (Broussard et al., 2014; Yang and Yuste, 2017), high-density electrophysiology (Buzsáki et al., 2015; Jun et al., 2017) and genome editing tools (Heidenreich and Zhang, 2016). Further, as we will outline in this review, it is possible to train rats to solve complex and demanding motor-cognitive tasks and precisely quantify (for example by high-speed videography, Rigosa et al., 2017; Nashaat et al., 2017) the kinematics of limb and whisker movements to 
A
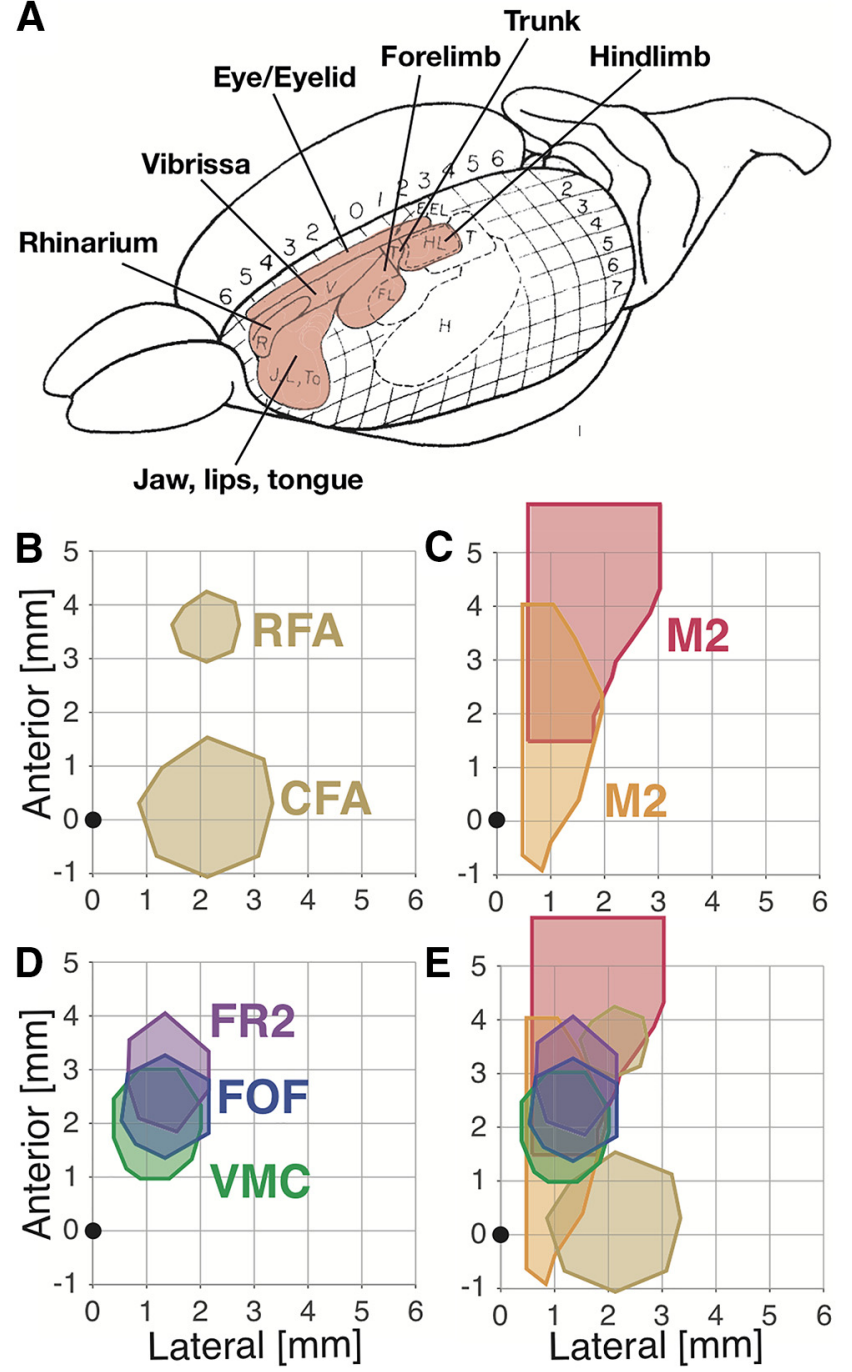

Figure 1. Maps of rat frontal cortex. A, Delineation of rat frontal cortex by intracortical microstimulation suggests a large, somatotopically organized primary motor representation (a ratunculus, indicated by shaded area; dashed lines indicate primary somatosensory cortex; adapted with permission from Hall and Lindholm, 1974). B , Forelimb movements can be evoked by stimulation of a posterior zone (CFA) and an anterior spot (RFA; bregma indicated by dot Neafsey and Sievert, 1982; Rouiller et al., 1993). C, Some publications consider an anterior region of rat frontal cortex as $\mathrm{M} 2$ (a putative homolog of primate supplementary motor areas, red; Murakami et al., 2014, 2017). Other publications assign M2 to a much more posterior region (orange; Mimica et al., 2018). D, The regions of rat frontal cortex referred to in the literature as primary VMC (Berg and Kleinfeld, 2003; Brecht et al., 2004a,b; Hill et al., 2011; Ebbesen et al., 2017), FOF (a putative homolog of the primate FEF; Erlich et al., 2011; Hanks et al., 2015; Kopec et al., 2015) and FR2 (Insanally et al., 2018) overlap. $\boldsymbol{E}$, Overlay of all the above regions.

investigate the temporal dynamics and outcome of decision making processes, spanning from known sensory input, across internal deliberation to final motor output (Ölveczky, 2011; Peters et al., 2017b; Svoboda and Li, 2018).

One obstacle to applying knowledge learned in rodents to understand primate cortex is that the correspondence between rodent and primate motor cortices is mostly unknown and that current naming schemes are inconsistent and confusing (Brecht, 2011). For example, tracing studies (Zingg et al., 2014) and classic delineation of rat frontal cortex by perithreshold intracortical microstimulation (Hall and Lindholm, 1974; Gioanni and Lamarche, 1985; Neafsey et al., 1986) suggests a large, somatotopically organized primary motor representation ("ratunculus"), that encompasses most of frontal cortex (Fig. 1A). However, the real picture is more complex and stimulation and anatomical tracing suggests, that forelimb movements, for example, are controlled by two, spatially segregated regions (caudal and rostral forelimb areas; Neafsey and Sievert, 1982; Rouiller et al., 1993; Fig. $1 B$ ). Nomenclature, that relies on comparative anatomy to name motor structures in the rat brain after their putative corresponding primate homologues, often suggest conflicting naming schemes. Thus, the same region of rat frontal cortex is referred to in the literature as primary vibrissa motor cortex (VMC; whisker M1; Brecht et al., 2004a,b; Berg and Kleinfeld, 2003; Hill et al., 2011; Ebbesen et al., 2017), secondary motor cortex (M2; a putative homolog of primate supplementary motor areas; Paxinos and Watson, 1982; Murakami et al., 2014, 2017; Mimica et al., 2018), the frontal orientation field (FOF; a putative homolog of the primate frontal eye field; Erlich et al., 2011; Hanks et al., 2015), frontal area 2 (FR2; Insanally et al., 2018), ventral frontal motor cortex (vFMCx; Lee et al., 2008) and medial agranular cortex (AGm; Smith and Alloway, 2013; Fig. 1C-E). In the mouse, the terminology is comparably varied and the same region also goes under several names, such as vibrissa/whisker motor cortex (vM1: Huber et al., 2012; wM1: Matyas et al., 2010; Sreenivasan et al., 2015; 2016), secondary motor cortex (M2; Schneider et al., 2014; Nelson and Mooney, 2016; Siniscalchi et al., 2016), medial agranular motor cortex (also M2; Nelson et al., 2013), frontal motor cortex (fMR; Goard et al., 2016), and secondary motor area (MOs; Allen Mouse Brain Atlas, Lein et al., 2007; Zingg et al., 2014). This variety of terminology is confusing and can hamper discovery and exchange both between primate and rodent researchers and within the rodent community.

Fortunately, the inconsistency in nomenclature has been beneficial in some ways. Because it is unclear which primate motor structures the various regions of rodent frontal cortex correspond to, this neuronal population has been investigated from very divergent vantage points, something that is actually rare in neuroscience, and implicated in a surprising variety of functions. Here, we review recent studies, which have investigated the role of rodent frontal cortex, in classic motor control of whisker and limb movements, in processing sensory stimuli, and in higherorder functions, such as motor decision-making, both in selfinitiated action and in tasks, that require integration of sensory information over time. We conclude by highlighting major open questions and future directions.

\section{Frontal control of whisker movements}

A relatively large portion of rodent motor cortex is involved in whisker control. Active vibrissal touch is a major sensing strategy of rats and mice, small nocturnal mammals who live in dark tunnels. These animals have evolved highly specialized neural circuitry for expert control of whisker movements. Rats move their whiskers individually during active touch sensing (Welker, 1964; Sachdev et al., 2002; O'Connor et al., 2010; Zuo et al., 2011; Voigts et al., 2015), in anticipation of head turning (Towal and Hartmann, 2006) and during social interactions (Wolfe et al., 2011). The fine motor control for active vibrissal touch mirrors the fine motor control of primate and human fingertips (Diamond, 2010; Prescott et al., 2011). Analogous to the enlarged representation of digital movements in the primate and human motor homunculus (Leyton and Sherrington, 1917; Penfield and Boldrey, 1937), the vibrissa motor representation in frontal cortex (as assessed by intracortical microstimulation) is huge, taking up $\sim 6.5 \%$ of the whole cortical sheet (Hall and Lindholm, 1974; Gioanni and Lamarche, 1985; Neafsey et al., 1986; Zilles and Wree, 1995; Brecht et al., 2004a). 


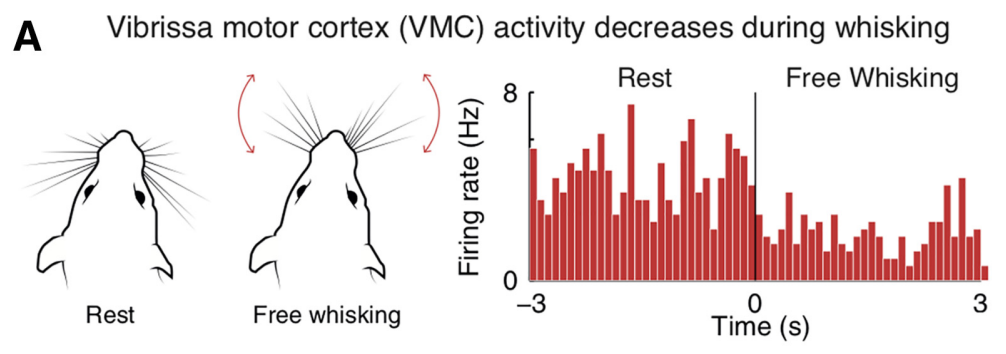

B

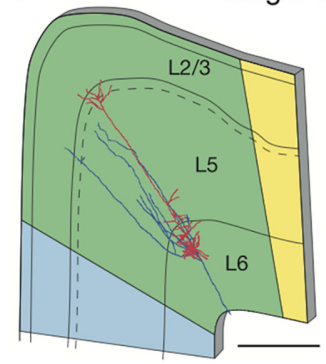

Single-cell stimulation elecits whisker retraction
C Normal whisking After VMC disinhibition

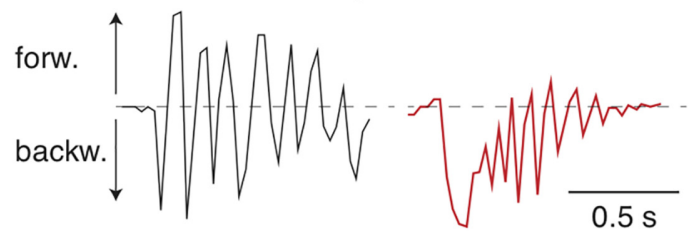

D VMC blockade increases contralateral whisking

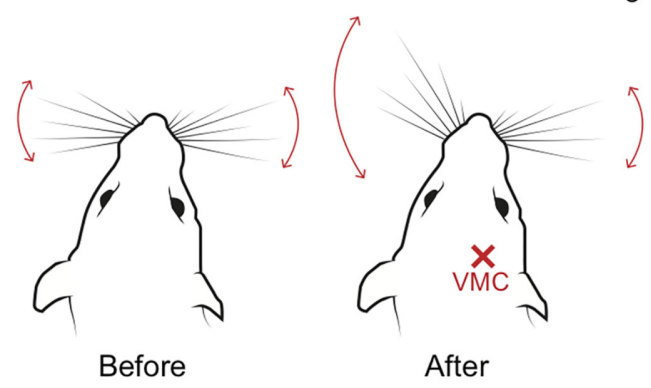

Figure 2. Investigating the role of VMC in the control of whisker movements. A, VMC activity decreases during various forms of whisking behavior. Left, Schematic depiction of vibrissal patterns at rest (whiskers retracted, no movement) and during bouts of exploratory whisking in air (whiskers protracted, moving). Right, Peristimulus time histogram of activity of a representative $L 5 \mathrm{VMC}$ neuron aligned to the onset of free whisking (adapted with permission from Ebbesen et al., 2017). B, Intracellular activation of single VMC neurons elicits whisker retractions. Left, Labeled L6 VMC neuron (green, VMC; red, dendrites; blue, axon). Scale bar, $500 \mu \mathrm{m}$. Right, Example intracellular trace from the same neuron showing evoked action potentials (below) and the elicited retraction of an E-row whisker (top, $\mathrm{f} / \mathrm{b}$ indicates forward/backward movements; adapted with permission from Brecht et al., 2004b). C, In rats, normal whisking consists of both forward and backward movements of the whiskers (black trace). Disinhibition of $V M C$ by $G A B A_{A}$ and $G A B A_{B}$ antagonists elicits whisker retractions (red trace), which are time-locked to disinhibition-induced bouts of increased multiunit activity in motor cortex (adapted with permission from Castro-Alamancos, 2006). D, In intact rats, whisking is similar on both sides. After unilateral blockade of VMC, the contralateral whiskers move forward and their whisking power increases (adapted with permission from Ebbesen et al., 2017).

Similarly to circuits controlling locomotion (Franz and Lashley, 1917; Kiehn, 2006), the whisking rhythm is generated subcortically by a central pattern generator in the brainstem reticular formation (Gao et al., 2001; Moore et al., 2013; Deschênes et al., 2016), but the way by which the VMC modulates brainstem circuits to select behaviorally appropriate movement output is still an open question. Just like in the primate distal limb system (Cheney and Fetz, 1980), there is a monosynaptic corticomotoneuronal pathway from layer 5 of VMC onto motoneurons in the facial nucleus but, in contrast to the primate system, these direct connections are extremely sparse (Grinevich et al., 2005; Sreenivasan et al., 2015). The vast majority of descending axons from the VMC affect motoneurons oligosynaptically and terminate onto brainstem interneurons (Hattox et al., 2002; Grinevich et al., 2005; Sreenivasan et al., 2015; Jeong et al., 2016). In general, the relationship between VMC activity and whisking kinematics is surprisingly weak; much weaker, for example, than the tight correlations between M1 activity and distal limb movements in primates (Lemon, 2008) or rodents (Isomura et al., 2009; Miri et al., 2017). Early studies identified single VMC neurons, whose activity significantly correlated with whisking kinematics, but- in contrast to the primate (Georgopoulos et al., 1982, 1986)- there was no relationship between population activity and whisking (Carvell et al., 1996; Hill et al., 2011; Friedman et al., 2012; Gerdjikov et al., 2013).

A population pattern has only begun to emerge in recent studies. One recent study (Sreenivasan et al., 2016) looked at the laminar distribution of activity during whisking in head fixed mice, and found an overall decrease in the activity of layer $2 / 3$ neurons during whisking. Neurons in layer 5 (corticofugal neurons) had a mixed response. At the population level, there was a tiny increase in the median, but a large increase in the mean layer 5 activity around the onset of whisking. This skewed firing rate distribution could indicate a role for a subpopulation of highfiring-rate VMC neurons in whisking initiation, perhaps analogous to how fast-spiking parvalbumin-expressing GABAergic neurons in forelimb motor cortex show strong increases around the onset of reaching movements (Estebanez et al., 2017). Another recent study investigated activity in layer 5 of VMC in freely moving rats during several types of self-initiated vibrissal behaviors: Exploratory whisking in the air, whisking to palpate objects and social whisking during facial interactions with conspecifics (Fig. 2A; Ebbesen et al., 2017). All whisking behaviors were associated with an $\sim 21 \%$ overall decrease in spike rates in layer 5 of VMC. Recordings from layer $5 \mathrm{VMC}$ neurons in socially interacting rats revealed that social whisking was associated with reduced cellular excitability and membrane hyperpolarization, suggesting increased inhibition during whisking (Ebbesen et al., 2017). These observations suggest that VMC gates the subcortical whisking pattern generator, such that a decrease in descending cortical input to downstream brainstem targets ultimately leads to whisker protraction and disinhibits whisking (Deschênes et al., 2016; Ebbesen et al., 2017; Guest et al., 2018).

Several other observations align with this "suppressive motor control" interpretation, chiefly among them the curious fact that while the whisker musculature and vibrissal motoneurons are laid out for forward movement of whiskers (Dörfl, 1982; Klein and Rhoades, 1985; Herfst and Brecht, 2008; Haidarliu et al., 2010; 2014), intracortical microstimulation of layer 5 (Hall and Lindholm, 1974; Gioanni and Lamarche, 1985; Neafsey et al., 1986; Berg and Kleinfeld, 2003; Brecht et al., 2004a; Haiss and Schwarz, 2005; Ferezou et al., 2007; Tandon et al., 2008; Matyas et al., 2010; Ebbesen et al., 2017) and even stimulation of single pyramidal neurons (Fig. 2B; Brecht et al., 2004b) in VMC almost exclusively evokes whisker retraction, not, as perhaps expected (Graziano et al., 2002; Graziano, 2016), the behaviorally relevant 
forward whisker movements. Observations after optogenetic manipulation (Sreenivasan et al., 2015, 2016; Auffret et al., 2018) are more mixed (Wolff and Ölveczky, 2018). Similarly, disinhibition of VMC by GABA antagonists induces myoclonic whisker retractions, which are time-locked to bouts of disinhibition-induced increases in multiunit activity (Fig. 2C; Castro-Alamancos, 2006). Mirroring the effects of VMC activation, unilateral lesioning (Gao et al., 2003) and unilateral inactivation (Ebbesen et al., 2017) of VMC moves the contralateral whiskers forward and increases whisking contralaterally (Fig. 2D).

\section{Frontal control of limb movements}

Stimulation and tracing studies implicate two frontal regions in the control of forelimb movements: caudal forelimb area (CFA) and rostral forelimb area (RFA; Fig. 1B; Neafsey and Sievert, 1982; Rouiller et al., 1993; Tennant et al., 2011). Both areas are activated during skilled forelimb movement and are essential for the execution of trained limb movement (Hira et al., 2013; Brown and Teskey, 2014; Guo et al., 2015; Schiemann et al., 2015; Miri et al., 2017; Morandell and Huber, 2017; Galiñanes et al., 2018), but the relationship between movement and spiking activity is dynamic (Peters et al., 2014, 2017a) and is different between RFA and CFA. For example, activity in RFA, but not in CFA, is sensitive to behavioral context (Saiki et al., 2014), contralateral movement bias of activity is weaker in RFA than CFA (Soma et al., 2017), and activity in RFA, but not CFA, is larger for externally triggered movements than internally triggered movements (Kimura et al., 2017).

Some observations indicate that RFA is a premotor structure, that represents higher-order information about movements, whereas CFA encodes concrete motor information, such as motor commands to the musculoskeletal system. However, the similarity of activity patterns and the effects of stimulation in RFA and CFA suggest that they are part of a highly integrated computational unit (Hyland, 1998; Harrison et al., 2012; Saiki et al., 2014; Hira et al., 2015; Morandell and Huber, 2017; Wang et al., 2017). In both RFA and CFA, two major types of deep layer pyramidal neurons send their axons to other areas: intratelencephalic (IT-type) neurons project bilaterally to the cerebral cortex and striatum, whereas extratelencephalic (ET-type) neurons, project to the thalamus, spinal cord and other areas ipsilaterally (Harris and Shepherd, 2015; Baker et al., 2018). In a study, in which spike patterns in CFA and RFA were separated by projection targets (determined by optogenetic stimulation), ET-type neurons showed postspike suppression in spike autocorrelograms, which was independent of behavioral conditions (Saiki et al., 2018). The CFA ET-type neurons exhibited larger bias toward contralateral movement compared with RFA, and IT-type neurons had a large fraction of bilateral movement activity especially in RFA (Soma et al., 2017).

\section{Sensory representations in frontal cortex}

Motor planning requires the integration of sensory input to generate appropriate motor output. Accordingly, the frontal motor cortex is widely connected to sensory cortices, including auditory, visual, and somatosensory cortex (Reep et al., 1987; Hoover and Vertes, 2007; Barthas and Kwan, 2017). Somatosensory signals in frontal motor cortex have been widely explored. Several motor cortical neurons have low-latency, "S1"-like responses to whisker deflection (Kleinfeld et al., 2002; Ferezou et al., 2007; Huber et al., 2012; Smith and Alloway, 2013; Zagha et al., 2015) and tactile stimulation of forelimbs (Estebanez et al., 2017). In addition, there are strong recurrent corticocortical connections between VMC and barrel cortex, the primary whisker representation in S1 (Mao et al., 2011; Kinnischtzke et al., 2014, 2016). Motor cortical feedback modulates sensory processing in S1 (Zagha et al., 2013; Manita et al., 2015) and motor cortical activity facilitates sensory responses in barrel cortex and the thalamus (Lee et al., 2008). Imaging of axonal projections from M1 to layer 1 barrel cortex while mice performed an object localization task has shown that M1 neurons carry information about task-related variables, including touch (Petreanu et al., 2012). Moreover, several studies have shown that layer 2/3 M1 neurons respond to both touch stimuli (whisker-dependent object detection) and motor behaviors such as whisker movements or licking during sensory go/no-go tasks (Huber et al., 2012; Zagha et al., 2015).

In addition to touch responsive neurons, some motor cortical neurons respond to auditory stimuli. In two regions of ferret frontal motor cortex, the dorsal orbital gyrus (a putative homolog of primate dorsolateral prefrontal cortex; Duque and McCormick, 2010) and anterior sigmoid gyrus (a putative homolog of primate premotor cortex; Fritz et al., 2010), trial-averaged spiking activity is modulated by auditory stimuli (tones or clicks) during a conditioned avoidance task, but only weakly modulated in a passive context where auditory stimuli were presented before behavior (Fritz et al., 2010). Frontal cortical neurons that were auditory responsive showed both suppression and enhancement of spiking activity to the target tone. Auditory-evoked responses have also been reported in mouse motor cortex during reaching (Estebanez et al., 2017) and licking (Siniscalchi et al., 2016) tasks. In the anterior part of mouse motor cortex, auditory-evoked responses are modulated by behavioral context (Siniscalchi et al., 2016). Auditory representations are present in PV + forelimb M1 neurons in the absence of sound-triggered movements, suggesting that sensory input alone can drive M1 neurons (Estebanez et al., 2017). Interestingly, PV + neurons in M1 are not indiscriminately driven by sensory input as the proportion of neurons that can be modulated by somatosensory input is greater than the proportion of neurons that are auditory-responsive suggesting a dissociation in sensory signals that can modulate PV + cells in M1 (Estebanez et al., 2017).

There are corticocortical connections between auditory cortex and mouse secondary motor cortex (Nelson et al., 2013; Nelson and Mooney, 2016) that contribute to suppressing sound-evoked responses in auditory cortex during locomotion (Schneider et al., 2014). These connections might be important for disambiguating self-generated sounds from other sounds in the environment (Schneider and Mooney, 2015), but motor cortex might also participate more directly in auditory processing. A recent study found that neurons in rat FR2 (Fig. 1D) were more informative about task-relevant auditory stimuli than auditory cortical neurons (Insanally et al., 2018). Although auditory cortex reliably responds to pure tones in untrained animals, when tones take on behavioral significance (i.e., when the animal is trained to respond to tones for food reward) stimulus information is more prevalent and pervasive in frontal cortex. An interspike-intervalbased decoder revealed that cells that appeared to be choiceselective when viewed at the level of the trial-averaged firing rate (i.e., cells that displayed "ramping activity") were found to be highly stimulus selective on single trials (Insanally et al., 2018).

Although it is well established that primate frontal cortices play a major role in visual sensorimotor transformations (Hatsopoulos and Suminski, 2011), we still know little about how rodent frontal motor cortices contribute to the processing of visual stimuli. Corticocortical projections from rodent frontal cortex relay motor-related signals to primary visual cortex (Zhang et al., 2014; 
Leinweber et al., 2017) and there are reciprocal connections between frontal motor cortex and higher visual areas (Itokazu et al., 2018). Frontal motor cortical neurons modulate their activity during the presentation of visual stimuli (Goard et al., 2016; Itokazu et al., 2018). However, population decoding did not provide significant information about the type of visual stimulus (horizontal vs vertical drifting gratings) in a go/no-go task (Goard et al., 2016). In a study where rats had to integrate sensory evidence in LED flashes, neurons in rat frontal motor cortex exhibited transient responses to visual stimulation and also encoded the amount of sensory evidence provided (Scott et al., 2017). Whether information about visual stimuli is embedded in spike timing (as was the case for auditory signals in rat FR2) remains an open question.

Together, these results suggest that motor cortex plays an important role in the processing of sensory input across several sensory modalities. Sensory signals in motor cortex might provide important feedback about ongoing motor programs for tuning motor output in the short term. In the long term, sensory feedback may be important for motor learning and behavioral strategizing, more generally. Lesion studies point to an important role of rodent frontal cortex in the learning of motor tasks (Huber et al., 2012; Kawai et al., 2015; Zagha et al., 2015) and motor cortical activity is reorganized across motor leaning (Laubach et al., 2000; Komiyama et al., 2010; Huber et al., 2012; Peters et al., 2014, 2017a; Makino et al., 2017; Miri et al., 2017; for review, see Peters et al., 2017b).

Ruling out covert muscular responses during sensory stimulation is difficult and seemingly "sensory" responses in motor cortices may actually be "motor" responses (e.g., preparatory activity, a gated movement or subtle, unnoticed movements). On the other hand, both somatosensory and motor cortex receive direct thalamic input (Deschênes et al., 1998; Ohno et al., 2012; Hooks et al., 2015), both areas project to the spinal cord and brainstem (Catsman-Berrevoets and Kuypers, 1976; Groos et al., 1978; Sreenivasan et al., 2015) and stimulation of either area elicits movements with low latency (Leyton and Sherrington, 1917; Penfield and Boldrey, 1937; Gioanni and Lamarche, 1985; Neafsey et al., 1986; Matyas et al., 2010; Sreenivasan et al., 2015), pointing to a role for both areas in motor control and sensory integration.

\section{Frontal control of action timing}

Motor control and decision-making involves not only choosing among multiple alternative options but also deciding when to act. Murakami et al. (2014) studied a role of rat secondary motor cortex in the action timing decision (M2; Fig. 1C). They used a waiting time decision task, where a rat had to decide how long to keep waiting for a delayed reward and when to give up and act for an immediately available, but less valuable option. Neural recording from M2 during this behavioral task revealed that firing rates in a subpopulation of M2 neurons encode the animal's waiting time. Such a firing-rate-based representation can feed into an integrator circuit, and be transformed into ramping activity and a mechanism to detect threshold crossing of the ramping activity could serve to generate a movement signal, at the end of a waiting period. Consistent with a role in an integration-to-threshold process, the authors found ramping activity during the waiting period, which reached a threshold level at the time of "give-up" behavior (Ratcliff, 1978; Gold and Shadlen, 2007). A similar neural signal of action timing is observed in primate premotor cortices in various contexts, for example ramp-to-threshold like responses in sensory decision tasks (Ding and Gold, 2012) and timing tasks (Lebedev et al., 2008; Mita et al., 2009). This suggests a conserved premotor mechanism, both in rodents and primates, in deciding and planning timing of future actions.

In contrast to M2, where a significant fraction of neurons encode waiting time in single trials, neurons in medial prefrontal cortex (mPFC; a major input structure of M2) contained very few neurons encoding the trial-to-trial waiting times (Murakami et al., 2017). Instead, mPFC neurons only encoded a slowly fluctuating component of waiting-time variability, a decision bias to wait shorter or longer, which fluctuated over $>10$ trials, and was modulated by previous experience. This finding is in line with the idea that higher-order areas, such as the PFC, can integrate information over time as well as space more extensively than lower sensory cortical areas (Hasson et al., 2008; Murray et al., 2014), and extends this idea to a motor domain: The prefrontal cortex contains information about decision biases or strategies that are adjusted slowly over time according to past integrated experiences and/or internal states, but it cares less about planning imminent actions. Instead, more dedicated motor areas, such as M2, are critical in planning what to do next and when to execute it, based on top-down influences from prefrontal areas.

\section{Frontal role in planning orienting movements}

The existence of a homolog of the primate frontal eye field (FEF) in rat frontal cortex was first suggested by Leonard (1969), based on similarities in connectivity with subcortical areas. Lesion (Reep et al., 2004) and microstimulation (Sinnamon and Galer, 1984) data supported that hypothesis. This may seem surprising, given that rats are not known for their visual abilities (Yilmaz and Meister, 2013; but see Seabrook et al., 2017). However, the primate FEF is not an "eye" field, but rather a "gaze" field or an orienting field. Microstimulation of FEF in animals who can freely move their heads generates coordinated head-eye movements (Knight and Fuchs, 2007) and the human FEF is activated when remembering spatial locations behind the head (Tark and Curtis, 2009). All bilaterally symmetric animals need to plan and generate orienting movements to actively sense the world (Ocaña et al., 2015). With that in mind, the idea of a homolog, a rat FOF, to the (poorly named) FEF seems less absurd.

To further investigate this homology Erlich et al. (2011) trained rats on a memory-guided orienting task (MGO) inspired by the classically FEF-dependent memory-guided saccade task (Funahashi et al., 1991; Chafee and Goldman-Rakic, 1998; Dias and Segraves, 1999). In the MGO task, rats must fixate during the presentation of a brief auditory cue (e.g., low-frequency = go left, high-frequency $=$ go right) and during a subsequent memory delay period (Fig. $3 A$ ). After a go cue, rats are rewarded if they orient to the correct side. Given that FOF is also VMC, Erlich et al. (2011) performed several control experiments to determine whether the rats were using a whisker strategy to perform the task. Neither shaving off the mystacial whiskers nor injecting lidocaine into the whisker pad on one side had a significant effect on behavior in well trained animals. Moreover, using video analysis, they showed that during the memory period the whiskers were retracted and rhythmic whisking was suppressed even as activity was ramping up (consistent with the findings described in "Frontal control of whisker movements"; Ebbesen et al., 2017).

Unilateral pharmacological inactivation of FOF resulted in an ipsilateral bias, similar to findings in primate FEF (Sommer et al., 1997; Dias and Segraves, 1999). Furthermore, neural activity during the memory-period predicted the upcoming choice of the animal, with neural encoding of the upcoming motor response that was low during the sensory cue, and gradually increased during the memory delay period (Fig. 3C). Temporally precise 
A Memory Guided Orienting
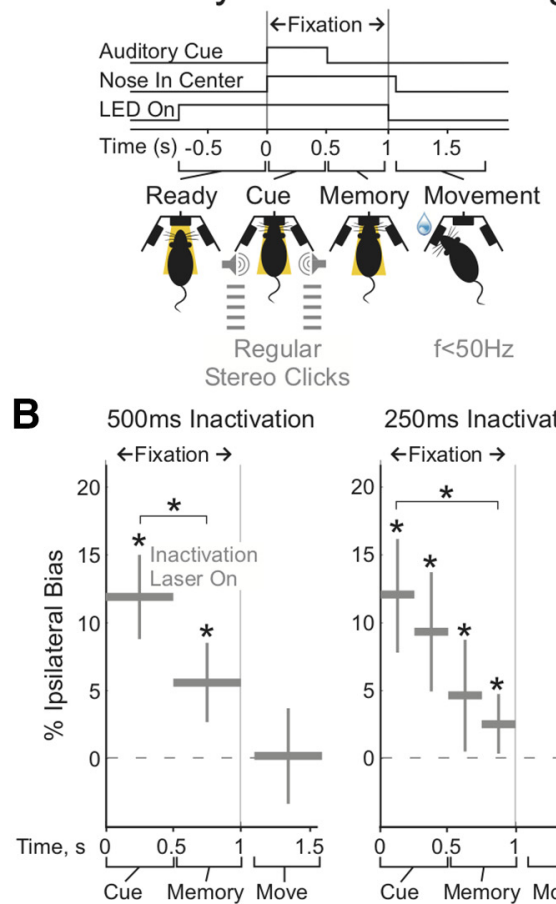

250ms Inactivation

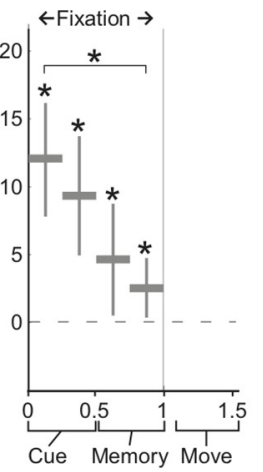

C
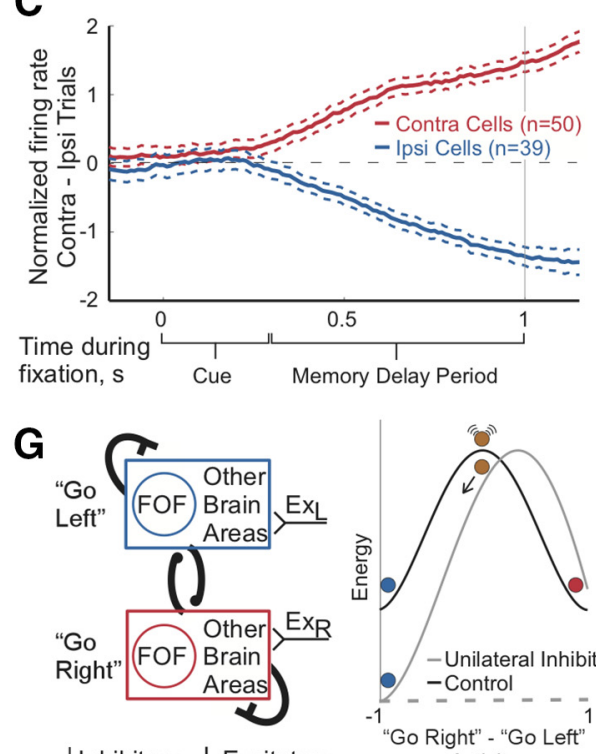

dInhibitory 人 Excitatory

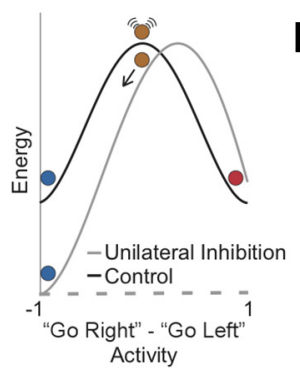

D
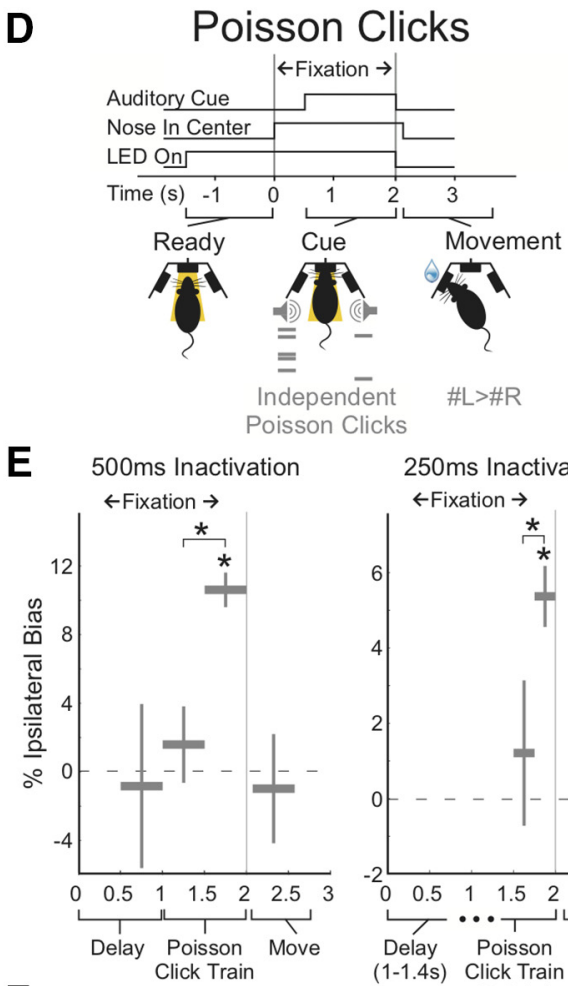

$\mathbf{F}$
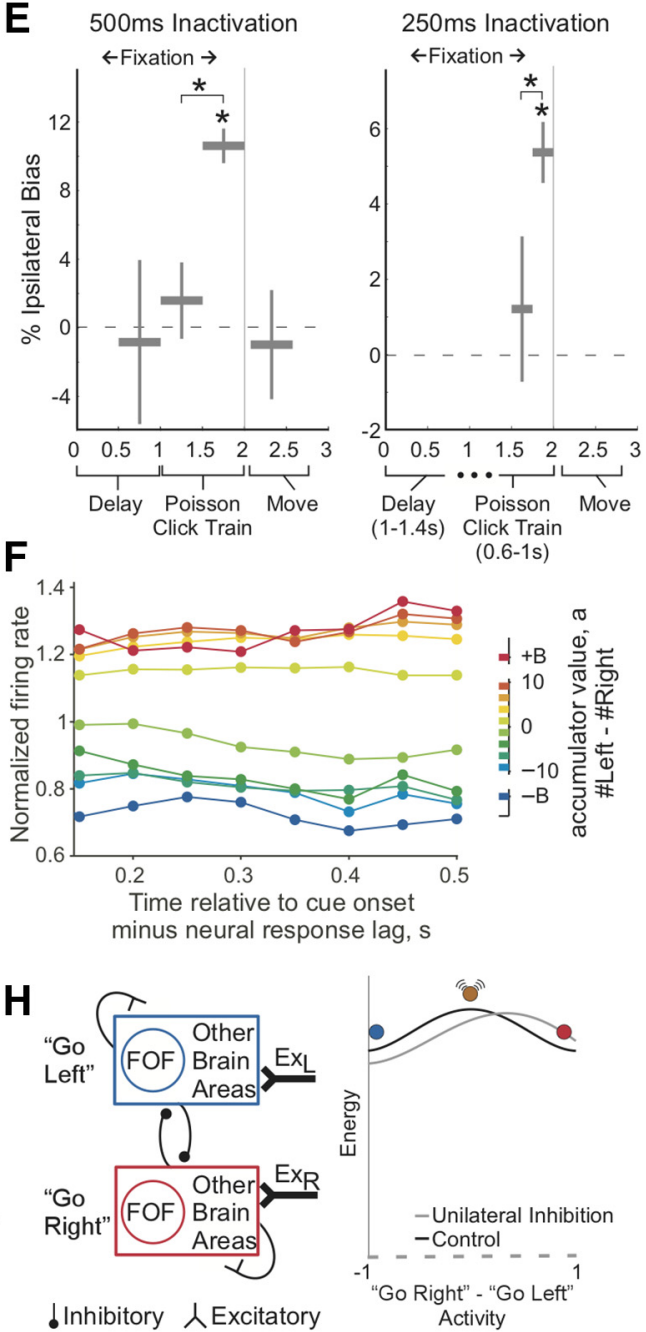

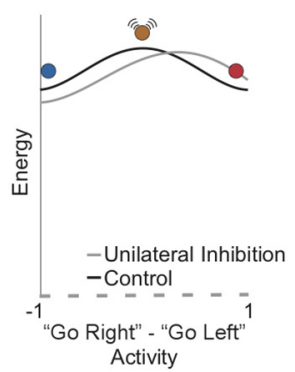

Figure 3. Investigating the role of the FOF in motor planning in two short-term memory decision making tasks. $A, M G O$ task structure. $B$, Unilateral inactivation of FOF with halorhodopsin. Inactivation period denoted by the horizontal extent of the bar. Choice bias magnitude reported relative to the hemisphere being inactivated. ${ }^{*} p<0.05$. Inactivation of FOF during the MG0 task biases choices most if it occurs early during the cue presentation. $C$, Neural encoding of the direction of the upcoming motor response grows monotonically in FOF during cue presentation and the short-term memory delay period. Solid lines show normalized firing rate in trials resulting in an orienting motion contralateral to the recorded neurons, minus normalized firing rate in trials resulting in an ipsilateral orienting motion (blue, average of $n=50$ contralateral-preferring neurons; red, 39 ipsi-preferring neurons). Dashed lines are \pm SEM. Data are reanalyzed from Erlich et al. (2011) and from correct trials only. $\boldsymbol{D}$, Poisson Clicks task structure. $\boldsymbol{E}$, Same as $\boldsymbol{B}$, but for the Clicks task. Inactivation of FOF during the Clicks task biases choices only if it overlaps the end of the cue presentation. $\boldsymbol{F}$, Average normalized firing rate of neurons in FOF as a function of the accumulated value of clicks (\#left - \#Right) and the time during the stimulus. Firing rates tend to fall into two stable clusters, indicating the accumulated value is less than (greater than) 0 at that moment in time and a right (left) response is preferred. G, Bistable attractor network model capable of replicating findings from FOF during the MGO task. Two populations of neurons whose activity signals a leftward or rightward orienting movement, self excite and mutually inhibit, and are composed of neurons from the FOF and other brain areas. Ex, External drive. Deep attractors stably encode information during the delay period but are more resistant to perturbation. $\boldsymbol{H}$, Same as $\boldsymbol{G}$, but for the Clicks task. Shallow attractors allow for a flexible motor plan, which can be updated as new information is integrated and allow the network to recover from early perturbations. $\boldsymbol{A}-\boldsymbol{C}, \boldsymbol{G}$, Adapted with permission from Kopec et al. (2015). E, F, Adapted with permission from Hanks et al. (2015).

unilateral optogenetic inactivation (halorhodopsin, eNpHR3.0) of the FOF revealed that inactivation during the first half of the cue period, the time of minimal information encoding, resulted in the largest ipsilateral choice bias, whereas inactivation during the second half of the memory period, the time of maximal information encoding, resulted in the smallest choice bias (Fig. 3B). Inactivation during the motor action resulted in no bias or change in movement kinetics (Kopec et al., 2015). 
To further investigate the role of FOF in orienting decisions, rats were also trained on a gradual accumulation of evidence task, the Poisson Clicks task (Brunton et al., 2013), similar to the primate random dot motion accumulation task (Shadlen and Newsome, 1996). In the Clicks task the cue consisted of two independent streams of Poisson timed auditory clicks with different underlying rates, presented from speakers to the animal's left and right, after which the rat must respond to the side that played more clicks (Fig. 3D). Only inactivation that overlapped the end of the auditory cue and fixation period resulted in a choice bias (Fig. 3E; Hanks et al., 2015).

The different inactivation effect timings between the MGO and Poisson Clicks tasks can be reconciled as due to the different demand for flexibility in the movement plan. In the Clicks task the randomly varying Poisson click times require a movement plan which can be updated as new information is accumulated. In the MGO task, on the other hand, the click train is periodic and there is no new information during the delay, so a rigid and robust movement plan is more appropriate.

Results from both tasks could be replicated by modeling the FOF as a bistable attractor network (Machens et al., 2005; Wong and Wang, 2006). In the MGO task the network rapidly falls into one of two strong basins of attraction required to maintain the information during the memory delay period (Fig. $3 G$ ). As the network settles, the information encoding increases (Erlich et al., 2011), and the network becomes more resistant to perturbation (Kopec et al., 2015). A similar model but with weaker attractors (Fig. $3 H$ ) is capable of replicating findings during the Poisson Clicks task (Erlich et al., 2015; Piet et al., 2017). Incoming information could more easily move the network between two categorical states, consistent with recordings of neurons in the FOF during the Clicks task (Fig. 3F; Hanks et al., 2015). This allowed the network to use information from the entire click train, implementing a flexible plan, which allows it to recover from perturbations early in the stimulus.

Despite the apparent parsimony of this description, many questions remain. According to these models, the FOF is just one element in a distributed network for planning orienting movements (Kopec et al., 2015). The superior colliculus has been identified as another key element, but possibly other prefrontal cortical areas (for planning directional licks, see Chen et al., 2017; Svoboda and Li, 2018) or subcortical regions such as thalamus and basal ganglia (Yartsev et al., 2018) play an important role as well. Moreover, the models do not explain the heterogeneity observed in the firing patterns of FOF neurons (Erlich et al., 2011; Hanks et al., 2015). Cell-type-specific recording and laminar recordings would create important constraints on future models.

\section{Conclusion and future directions}

In this review, we summarized some recent investigations into the mechanisms by which rodent frontal cortex contributes to: active-sensing with whisking, preparation and execution of limb movements, sensory-coding, and preparation and execution of orienting movements. While the cortical regions subserving limb movements (CFA and RFA) are fairly well demarcated (Fig. 1A), the other functions reviewed are all found in a highly overlapping region of rat motor cortex (Fig. 1D-E). Is the diversity of function revealed here a specialty of rat frontal cortex? It is tempting to speculate that the smaller brain of the rodent (compared with human or macaque) creates less pressure for wiring efficiency (Chklovskii et al., 2002) and this results in neurons with distinct functional roles intermixed in the cortical surface. Thus, although the enlarged whisker representation in rodent motor cor- tex (Fig. 1A) mirrors the enlarged distal limb representation in primate $\mathrm{M} 1$, the same area also shares similarities with other frontal premotor structures in the primate brain.

A possible role of rodent frontal cortex in tuning (Hill et al., 2011; Friedman et al., 2012; Gerdjikov et al., 2013) and initiating (Sreenivasan et al., 2016) whisker movements is similar to motor control by primate $\mathrm{M} 1$, but a prominent role in whisker movement suppression (Ebbesen et al., 2017) is not. In humans and primates, other prefrontal and frontal structures than M1 are paramount for behavioral inhibition and movement suppression (Miller, 2000; Kim and Lee, 2011). For example, neurons in the supplementary eye field play an important role in saccade suppression and countermanding (Schall et al., 2002; Carpenter, 2004; Stuphorn et al., 2010; Shadmehr, 2017) and the presupplementary and supplementary motor areas (SMA) are crucial for voluntary movement inhibition (Nachev et al., 2008; Chen et al., 2010; Wardak, 2011; Filevich et al., 2012a,b). Similarly to how VMC lesions (Gao et al., 2003) or inactivation (Ebbesen et al., 2017) increases whisking, lesions to the SMA evokes involuntary, "alien" movements in humans (Brainin et al., 2008). Further investigations of movement suppression by rat motor cortex could be a way to explore the evolutionary origins of behavioral inhibition by frontal cortex more generally (Laubach et al., 2015; Barthas and Kwan, 2017; Ebbesen and Brecht, 2017).

Similar to the control of vibrissal touch by rat motor cortices, the primate FEF is involved in active-sensing (i.e., visual search; Bichot et al., 2001). Like rat motor cortices, the FEF contains neurons with short-latency sensory responses (Joiner et al., 2017). During action timing and perceptual decision-making, some FEF neurons ramp to threshold before an orienting response (Ding and Gold, 2012) and encode cognitive aspects of decision-making (Teichert et al., 2014). Similar to rat motor cortices during orienting movements, the FEF can be modeled with attractor dynamics (Wimmer et al., 2014). Despite these similarities there are also important differences. The primate FEF plays a direct role in eye movements and visuospatial attention (Moore and Fallah, 2001; Noudoost and Moore, 2011; Gregoriou et al., 2014) and provides an attention-like modulation of visual cortical activity (Moore and Armstrong, 2003; Ekstrom et al., 2008). The tight integration between primate FEF and the oculomotor system is mirrored by similar observations on the human FEF (Grosbras and Paus, 2002) and by studies on the forebrain gazecontrol area of the barn owl (a putative avian homolog of primate FEF; Winkowski and Knudsen, 2006; Knudsen, 2007). Like the primate FEF (Merrikhi et al., 2017), rodent frontal motor cortex modulates the activity of the superior colliculus and both primary and higher-order visual areas (Zhang et al., 2014; Leinweber et al., 2017; Itokazu et al., 2018), but, as outlined in this review, unlike primate FEF, rodent frontal motor cortex is much more integrated with the whisker somatomotor system than with the visual system.

The differences between the results in primate FEF and rodent frontal motor cortex may be related to sensorimotor specializations. The FEF has mostly been studied in humans and monkeys, species with foveal vision. For animals with fovea, the target of fixation is almost always the focus of attention and cognition. The peripheral visual system determines how to shift that focus. This generates strong pressure for a tight connection between visual input and the orienting system. As mentioned, rats and mice are adapted for navigating in burrows. Their mystacial whiskers are analogous to the peripheral visual system and their microvibrissa (the small whiskers around the mouth and nose) are analogous to foveal vision (Grant et al., 2012). A dangerous object 
(e.g., a snake) detected via the mystacial whiskers should lead to rapid orienting away from the object. Conversely, a delicious object (e.g., a cricket) should lead to rapid orienting toward that object (Anjum et al., 2006). Thus, as the primate FEF directs spatial attention through its close integration with the visual and oculomotor systems, this region of rodent motor cortex can be considered an orientation field, directing spatial attention through its close integration with the whisker and orienting systems. However, it is well documented that primate FEF plays a role in spatial working memory and spatial attention even when subjects are not planning a movement (Tark and Curtis, 2009; Squire et al., 2013). It remains to be seen whether this is also true of rodent FOF.

This idea fits well with other observations. For example, while the primate superior colliculus is a primarily visuomotor structure (Basso and May, 2017), the rodent superior colliculus plays a major role in integrating vibrissal touch information and controlling vibrissa movement (Miyashita and Mori, 1995; Hemelt and Keller, 2007, 2008; Bezdudnaya and Castro-Alamancos, 2014). In line with a role in head and whisker orienting, head and neck posture modulates activity in rodent frontal motor cortex (Mimica et al., 2018). Moreover, because orienting the whisker field toward a stimulus left or right of the snout requires retracting the whiskers on one side and bringing the whiskers on the opposite side forward, this might help explain why rodent frontal motor cortex field appears so heavily involved in whisker retraction (Ebbesen et al., 2017).

Rodents have great potential as comparative model organisms in motor research. To unlock this potential, it is vital to maintain a broad ethological perspective (Krakauer et al., 2017) and remember two key points: (1) Rodents are not small primates, but have distinct sensorimotor specializations. Neural circuits for control of foveal vision in primates may be mirrored by circuits for sensing by active vibrissal touch in mice and rats. (2) In contrast to sharply delineated motor structures in primates, rodent cortical boundaries are blurry and cortical areas overlap. The same region of rat frontal cortex (Fig. $1 C-E$ ) shares similarities with multiple motor and premotor structures in the primate brain (e.g., M1, SMA, and FEF). With these points in mind, investigations of rodent motor cortices, such as the ones reviewed here, can help advance our understanding of the evolution and specialization of neural circuits for sensorimotor cognition across phylogeny.

\section{References}

Anjum F, Turni H, Mulder PG, van der Burg J, Brecht M (2006) Tactile guidance of prey capture in etruscan shrews. Proc Natl Acad Sci U SA 103:16544-16549. CrossRef Medline

Asanuma H (1975) Recent developments in the study of the columnar arrangement of neurons within the motor cortex. Physiol Rev 55:143-156. CrossRef Medline

Auffret M, Ravano VL, Rossi GMC, Hankov N, Petersen MFA, Petersen CCH (2018) Optogenetic stimulation of cortex to map evoked whisker movements in awake head-restrained mice. Neuroscience 368:199-213. CrossRef Medline

Baker A, Kalmbach B, Morishima M, Kim J, Juavinett A, Li N, Dembrow N (2018) Specialized subpopulations of deep-layer pyramidal neurons in the neocortex: bridging cellular properties to functional consequences. J Neurosci 38:5441-5455. CrossRef Medline

Barthas F, Kwan AC (2017) Secondary motor cortex: where "sensory" meets "motor" in the rodent frontal cortex. Trends Neurosci 40:181-193. CrossRef Medline

Basso MA, May PJ (2017) Circuits for action and cognition: a view from the superior colliculus. Annu Rev Vis Sci 3:197-226. CrossRef Medline

Berg RW, Kleinfeld D (2003) Vibrissa movement elicited by rhythmic elec- trical microstimulation to motor cortex in the aroused rat mimics exploratory whisking. J Neurophysiol 90:2950-2963. CrossRef Medline

Bezdudnaya T, Castro-Alamancos MA (2014) Neuromodulation of whisking related neural activity in superior colliculus. J Neurosci 34:7683-7695. CrossRef Medline

Bichot NP, Thompson KG, Chenchal Rao S, Schall JD (2001) Reliability of macaque frontal eye field neurons signaling saccade targets during visual search. J Neurosci 21:713-725. CrossRef Medline

Brainin M, Seiser A, Matz K (2008) The mirror world of motor inhibition: the alien hand syndrome in chronic stroke. J Neurol Neurosurg Psychiatry 79:246-252. CrossRef Medline

Brecht M (2011) Movement, confusion, and orienting in frontal cortices. Neuron 72:193-196. CrossRef Medline

Brecht M, Krauss A, Muhammad S, Sinai-Esfahani L, Bellanca S, Margrie TW (2004a) Organization of rat vibrissa motor cortex and adjacent areas according to cytoarchitectonics, microstimulation, and intracellular stimulation of identified cells. J Comp Neurol 479:360-373. CrossRef Medline

Brecht M, Schneider M, Sakmann B, Margrie TW (2004b) Whisker movements evoked by stimulation of single pyramidal cells in rat motor cortex. Nature 427:704-710. CrossRef Medline

Broussard GJ, Liang R, Tian L (2014) Monitoring activity in neural circuits with genetically encoded indicators. Front Mol Neurosci 7:97. CrossRef Medline

Brown AR, Teskey GC (2014) Motor cortex is functionally organized as a set of spatially distinct representations for complex movements. J Neurosci 34:13574-13585. CrossRef Medline

Brunton BW, Botvinick MM, Brody CD (2013) Rats and humans can optimally accumulate evidence for decision-making. Science 340:95-98. CrossRef Medline

Buzsáki G, Stark E, Berényi A, Khodagholy D, Kipke DR, Yoon E, Wise KD (2015) Tools for probing local circuits: high-density silicon probes combined with optogenetics. Neuron 86:92-105. CrossRef Medline

Carpenter RH (2004) Supplementary eye field: keeping an eye on eye movement. Curr Biol 14:R416-418. CrossRef Medline

Carvell GE, Miller SA, Simons DJ (1996) The relationship of vibrissal motor cortex unit activity to whisking in the awake rat. Somatosens Mot Res 13:115-127. CrossRef Medline

Castro-Alamancos MA (2006) Vibrissa myoclonus (rhythmic retractions) driven by resonance of excitatory networks in motor cortex. J Neurophysiol 96:1691-1698. CrossRef Medline

Catsman-Berrevoets CE, Kuypers HG (1976) Cells of origin of cortical projections to dorsal column nuclei, spinal cord and bulbar medial reticular formation in the rhesus monkey. Neurosci Lett 3:245-252. CrossRef Medline

Chafee MV, Goldman-Rakic PS (1998) Matching patterns of activity in primate prefrontal area $8 \mathrm{a}$ and parietal area 7ip neurons during a spatial working memory task. J Neurophysiol 79:2919-2940. CrossRef Medline

Chen X, Scangos KW, Stuphorn V (2010) Supplementary motor area exerts proactive and reactive control of arm movements. J Neurosci 30:1465714675. CrossRef Medline

Cheney PD, Fetz EE (1980) Functional classes of primate corticomotoneuronal cells and their relation to active force. J Neurophysiol 44:773-791. CrossRef Medline

Chen TW, Li N, Daie K, Svoboda K (2017) A map of anticipatory activity in mouse motor cortex. Neuron 94:866-879.e4. CrossRef Medline

Chklovskii DB, Schikorski T, Stevens CF (2002) Wiring optimization in cortical circuits. Neuron 34:341-347. CrossRef Medline

Deisseroth K (2015) Optogenetics: 10 years of microbial opsins in neuroscience. Nat Neurosci 18:1213-1225. CrossRef Medline

Deschênes M, Takatoh J, Kurnikova A, Moore JD, Demers M, Elbaz M, Furuta T, Wang F, Kleinfeld D (2016) Inhibition, not excitation, drives rhythmic whisking. Neuron 90:374-387. CrossRef Medline

Deschênes M, Veinante P, Zhang ZW (1998) The organization of corticothalamic projections: reciprocity versus parity. Brain Res Rev 28: $286-$ 308. CrossRef Medline

Diamond ME (2010) Texture sensation through the fingertips and the whiskers. Curr Opin Neurobiol 20:319-327. CrossRef Medline

Dias EC, Segraves MA (1999) Muscimol-induced inactivation of monkey frontal eye field: effects on visually and memory-guided saccades. J Neurophysiol 81:2191-2214. CrossRef Medline

Ding L, Gold JI (2012) Neural correlates of perceptual decision making be- 
fore, during, and after decision commitment in monkey frontal eye field. Cereb Cortex 22:1052-1067. CrossRef Medline

di Pellegrino G, Fadiga L, Fogassi L, Gallese V, Rizzolatti G (1992) Understanding motor events: a neurophysiological study. Exp Brain Res 91: 176-180. CrossRef Medline

Dörfl J (1982) The musculature of the mystacial vibrissae of the white mouse. J Anat 135:147-154. Medline

Duque A, McCormick DA (2010) Circuit-based localization of ferret prefrontal cortex. Cereb Cortex 20:1020-1036. CrossRef Medline

Dushanova J, Donoghue J (2010) Neurons in primary motor cortex engaged during action observation. Eur J Neurosci 31:386-398. CrossRef Medline

Ebbesen CL, Brecht M (2017) Motor cortex: to act or not to act? Nat Rev Neurosci 18:694-705. CrossRef Medline

Ebbesen CL, Doron G, Lenschow C, Brecht M (2017) Vibrissa motor cortex activity suppresses contralateral whisking behavior. Nat Neurosci 20:8289. CrossRef Medline

Ekstrom LB, Roelfsema PR, Arsenault JT, Bonmassar G, Vanduffel W (2008) Bottom-up dependent gating visual cortex. Science 321:414-417. CrossRef Medline

Erlich JC, Bialek M, Brody CD (2011) A cortical substrate for memoryguided orienting in the rat. Neuron 72:330-343. CrossRef Medline

Erlich JC, Brunton BW, Duan CA, Hanks TD, Brody CD (2015) Distinct effects of prefrontal and parietal cortex inactivations on an accumulation of evidence task in the rat. eLife 4:e05457. CrossRef Medline

Estebanez L, Hoffmann D, Voigt BC, Poulet JFA (2017) Parvalbuminexpressing GABAergic neurons in primary motor cortex signal reaching. Cell Rep 20:308-318. CrossRef Medline

Evarts EV (1968) Relation of pyramidal tract activity to force exerted during voluntary movement. J Neurophysiol 31:14-27. CrossRef Medline

Ferezou I, Haiss F, Gentet LJ, Aronoff R, Weber B, Petersen CC (2007) Spatiotemporal dynamics of cortical sensorimotor integration in behaving mice. Neuron 56:907-923. CrossRef Medline

Fetz EE (1992) Are movement parameters recognizable coded in the activity of single neurons? Behav Brain Sci 15:679-690. CrossRef

Filevich E, Kühn S, Haggard P (2012a) Intentional inhibition in human action: the power of "no". Neurosci Biobehav Rev 36:1107-1118. CrossRef Medline

Filevich E, Kühn S, Haggard P (2012b) Negative motor phenomena in cortical stimulation: implications for inhibitory control of human action. Cortex 48:1251-1261. CrossRef Medline

Franz SI, Lashley KS (1917) The retention of habits by the rat after destruction of the frontal portion of the cerebrum. Psychobiology 1:3-18. CrossRef

Friedman WA, Zeigler HP, Keller A (2012) Vibrissae motor cortex unit activity during whisking. J Neurophysiol 107:551-563. CrossRef Medline

Fritz JB, David SV, Radtke-Schuller S, Yin P, Shamma SA (2010) Adaptive, behaviorally gated, persistent encoding of task-relevant auditory information in ferret frontal cortex. Nat Neurosci 13:1011-1019. CrossRef Medline

Funahashi S, Bruce CJ, Goldman-Rakic PS (1991) Neuronal activity related to saccadic eye movements in the monkey's dorsolateral prefrontal cortex. J Neurophysiol 65:1464-1483. CrossRef Medline

Galiñanes GL, Bonardi C, Huber D (2018) Directional reaching for water as a cortex-dependent behavioral framework for mice. Cell Rep 22:27672783. CrossRef Medline

Gao P, Bermejo R, Zeigler HP (2001) Whisker deafferentation and rodent whisking patterns: behavioral evidence for a central pattern generator. J Neurosci 21:5374-5380. CrossRef Medline

Gao P, Hattox AM, Jones LM, Keller A, Zeigler HP (2003) Whisker motor cortex ablation and whisker movement patterns. Somatosens Mot Res 20:191-198. CrossRef Medline

Georgopoulos AP, Kalaska JF, Caminiti R, Massey JT (1982) On the relations between the direction of two-dimensional arm movements and cell discharge in primate motor cortex. J Neurosci 2:1527-1537. CrossRef Medline

Georgopoulos AP, Schwartz AB, Kettner RE (1986) Neuronal population coding of movement direction. Science 233:1416-1419. CrossRef Medline

Gerdjikov TV, Haiss F, Rodriguez-Sierra OE, Schwarz C (2013) Rhythmic whisking area (RW) in rat primary motor cortex: an internal monitor of movement-related signals? J Neurosci 33:14193-14204. CrossRef Medline

Gioanni Y, Lamarche M (1985) A reappraisal of rat motor cortex organization by intracortical microstimulation. Brain Res 344:49-61. CrossRef Medline

Goard MJ, Pho GN, Woodson J, Sur M (2016) Distinct roles of visual, parietal, and frontal motor cortices in memory-guided sensorimotor decisions. eLife 5:e13764. CrossRef Medline

Gold JI, Shadlen MN (2007) The neural basis of decision making. Annu Rev Neurosci 30:535-574. CrossRef Medline

Grant RA, Sperber AL, Prescott TJ (2012) The role of orienting in vibrissal touch sensing. Front Behav Neurosci 6:39. CrossRef Medline

Graziano MSA (2016) Ethological action maps: a paradigm shift for the motor cortex. Trends Cogn Sci 20:121-132. CrossRef Medline

Graziano MS, Taylor CS, Moore T (2002) Complex movements evoked by microstimulation of precentral cortex. Neuron 34:841-851. CrossRef Medline

Gregoriou GG, Rossi AF, Ungerleider LG, Desimone R (2014) Lesions of prefrontal cortex reduce attentional modulation of neuronal responses and synchrony in V4. Nat Neurosci 17:1003-1011. CrossRef Medline

Grinevich V, Brecht M, Osten P (2005) Monosynaptic pathway from rat vibrissa motor cortex to facial motor neurons revealed by lentivirus-based axonal tracing. J Neurosci 25:8250-8258. CrossRef Medline

Groos WP, Ewing LK, Carter CM, Coulter JD (1978) Organization of corticospinal neurons in the cat. Brain Res 143:393-419. CrossRef Medline

Grosbras MH, Paus T (2002) Transcranial magnetic stimulation of the human frontal eye field: effects on visual perception and attention. J Cogn Neurosci 14:1109-1120. CrossRef Medline

Guest JM, Seetharama MM, Wendel ES, Strick PL, Oberlaender M (2018) 3 D reconstruction and standardization of the rat facial nucleus for precise mapping of vibrissal motor networks. Neuroscience 368:171-186. CrossRef Medline

Guo JZ, Graves AR, Guo WW, Zheng J, Lee A, Rodríguez-González J, Li N, Macklin JJ, Phillips JW, Mensh BD, Branson K, Hantman AW (2015) Cortex commands the performance of skilled movement. eLife 4:e10774. CrossRef Medline

Haidarliu S, Simony E, Golomb D, Ahissar E (2010) Muscle architecture in the mystacial pad of the rat. Anat Rec (Hoboken) 293:1192-1206. CrossRef Medline

Haidarliu, S., Kleinfeld, D., Deschênes, M., and Ahissar, E (2014) The musculature that drives active touch by vibrissae and nose in mice. Anat Rec (Hoboken) 298:1347-1358. CrossRef Medline

Haiss F, Schwarz C (2005) Spatial segregation of different modes of movement control in the whisker representation of rat primary motor cortex. J Neurosci 25:1579-1587. CrossRef Medline

Hall RD, Lindholm EP (1974) Organization of motor and somatosensory neocortex in the albino rat. Brain Res 66:23-38. CrossRef

Hanks TD, Kopec CD, Brunton BW, Duan CA, Erlich JC, Brody CD (2015) Distinct relationships of parietal and prefrontal cortices to evidence accumulation. Nature 520:220-223. CrossRef Medline

Harris JA, Hirokawa KE, Sorensen SA, Gu H, Mills M, Ng LL, Bohn P, Mortrud M, Ouellette B, Kidney J, Smith KA, Dang C, Sunkin S, Bernard A, Oh SW, Madisen L, Zeng H (2014) Anatomical characterization of cre driver mice for neural circuit mapping and manipulation. Front Neural Circuits 8:76. CrossRef Medline

Harris KD, Shepherd GM (2015) The neocortical circuit: themes and variations. Nat Neurosci 18:170-181. CrossRef Medline

Harrison TC, Ayling OG, Murphy TH (2012) Distinct cortical circuit mechanisms for complex forelimb movement and motor map topography. Neuron 74:397-409. CrossRef Medline

Hasson U, Yang E, Vallines I, Heeger DJ, Rubin N (2008) A hierarchy of temporal receptive windows in human cortex. J Neurosci 28:2539-2550. CrossRef Medline

Hatsopoulos NG, Suminski AJ (2011) Sensing with the motor cortex. Neuron 72:477-487. CrossRef Medline

Hattox AM, Priest CA, Keller A (2002) Functional circuitry involved in the regulation of whisker movements. J Comp Neurol 442:266-276. CrossRef Medline

Heidenreich M, Zhang F (2016) Applications of CRISPR-cas systems in neuroscience. Nat Rev Neurosci 17:36-44. CrossRef Medline

Heldt SA, Ressler KJ (2009) The use of lentiviral vectors and Cre/loxP to 
investigate the function of genes in complex behaviors. Front Mol Neurosci 2:22. CrossRef Medline

Hemelt ME, Keller A (2007) Superior sensation: superior colliculus participation in rat vibrissa system. BMC Neurosci 8:12. CrossRef Medline

Hemelt ME, Keller A (2008) Superior colliculus control of vibrissa movements. J Neurophysiol 100: 1245-1254. CrossRef Medline

Herfst LJ, Brecht M (2008) Whisker movements evoked by stimulation of single motor neurons in the facial nucleus of the rat. J Neurophysiol 99:2821-2832. CrossRef Medline

Hill DN, Curtis JC, Moore JD, Kleinfeld D (2011) Primary motor cortex reports efferent control of vibrissa motion on multiple timescales. Neuron 72:344-356. CrossRef Medline

Hira R, Ohkubo F, Tanaka YR, Masamizu Y, Augustine GJ, Kasai H, Matsuzaki M (2013) In vivo optogenetic tracing of functional corticocortical connections between motor forelimb areas. Front Neural Circuits 7:55. CrossRef Medline

Hira R, Terada S, Kondo M, Matsuzaki M (2015) Distinct functional modules for discrete and rhythmic forelimb movements in the mouse motor cortex. J Neurosci 35:13311-13322. CrossRef Medline

Hooks BM, Lin JY, Guo C, Svoboda K (2015) Dual-channel circuit mapping reveals sensorimotor convergence in the primary motor cortex. J Neurosci 35:4418-4426. CrossRef Medline

Hoover WB, Vertes RP (2007) Anatomical analysis of afferent projections to the medial prefrontal cortex in the rat. Brain Struct Funct 212:149-179. CrossRef Medline

Huber D, Gutnisky DA, Peron S, O’Connor DH, Wiegert JS, Tian L, Oertner TG, Looger LL, Svoboda K (2012) Multiple dynamic representations in the motor cortex during sensorimotor learning. Nature 484:473-478. CrossRef Medline

Hyland B (1998) Neural activity related to reaching and grasping in rostral and caudal regions of rat motor cortex. Behav Brain Res 94:255-269. CrossRef Medline

Insanally, M.N., Carcea, I., Field, R.E., Rodgers, C.C., DePasquale, B., Rajan, K., DeWeese, M.R., Albanna, B.F., and Froemke, R.C (2018) Nominally non-responsive frontal and sensory cortical cells encode task-relevant variables via ensemble consensus-building. bioRxiv Advance online publication. Retrieved on June 28, 2018. doi: 10.1101/347617.

Isomura Y, Harukuni R, Takekawa T, Aizawa H, Fukai T (2009) Microcircuitry coordination of cortical motor information in self-initiation of voluntary movements. Nat Neurosci 12:1586-1593. CrossRef Medline

Itokazu T, Hasegawa M, Kimura R, Osaki H, Albrecht UR, Sohya K, Chakrabarti S, Itoh H, Ito T, Sato TK, Sato TR (2018) streamlined sensory motor communication through cortical reciprocal connectivity in a visually guided eye movement task. Nat Commun 9:338. CrossRef Medline

Jeong M, Kim Y, Kim J, Ferrante DD, Mitra PP, Osten P, Kim D (2016) Comparative three-dimensional connectome map of motor cortical projections in the mouse brain. Sci Rep 6:20072. CrossRef Medline

Joiner WM, Cavanaugh J, Wurtz RH, Cumming BG (2017) Visual responses in FEF, unlike V1, primarily reflect when the visual context renders a receptive field salient. J Neurosci 37:9871-9879. CrossRef Medline

Jun JJ, Steinmetz NA, Siegle JH, Denman DJ, Bauza M, Barbarits B, Lee AK, Anastassiou CA, Andrei A, Aydın Ç, Aydın Ç, Barbic M, Blanche TJ, Bonin V, Couto J, Dutta B, Gratiy SL, Gutnisky DA, Häusser M, Karsh B, et al. (2017) Fully integrated silicon probes for high-density recording of neural activity. Nature 551:232-236. CrossRef Medline

Kawai R, Markman T, Poddar R, Ko R, Fantana AL, Dhawale AK, Kampff AR, Ölveczky BP (2015) Motor cortex is required for learning but not for executing a motor skill. Neuron 86: 800-812. CrossRef Medline

Kiehn O (2006) Locomotor circuits in the mammalian spinal cord. Annu Rev Neurosci 29:279-306. CrossRef Medline

Kilner JM, Lemon RN (2013) What we know currently about mirror neurons. Curr Biol 23:R1057-R1062. CrossRef Medline

Kim CK, Adhikari A, Deisseroth K (2017) Integration of optogenetics with complementary methodologies in systems neuroscience. Nat Rev Neurosci 18:222-235. CrossRef Medline

Kim S, Lee D (2011) Prefrontal cortex and impulsive decision making. Biol Psychiatry 69:1140-1146. CrossRef Medline

Kimura R, Saiki A, Fujiwara-Tsukamoto Y, Sakai Y, Isomura Y (2017) Large-scale analysis reveals populational contributions of cortical spike rate and synchrony to behavioural functions. J Physiol 595:385-413. CrossRef Medline
Kinnischtzke AK, Simons DJ, Fanselow EE (2014) Motor cortex broadly engages excitatory and inhibitory neurons in somatosensory barrel cortex. Cereb Cortex 24: 2237-2248. CrossRef Medline

Kinnischtzke AK, Fanselow EE, Simons DJ (2016) Target-specific M1 inputs to infragranular S1 pyramidal neurons. J Neurophysiol 116:12611274. CrossRef Medline

Klein BG, Rhoades RW (1985) Representation of whisker follicle intrinsic musculature in the facial motor nucleus of the rat. J Comp Neurol 232: 55-69. CrossRef Medline

Kleinfeld D, Sachdev RN, Merchant LM, Jarvis MR, Ebner FF (2002) Adaptive filtering of vibrissa input in motor cortex of rat. Neuron 34:10211034. CrossRef Medline

Knight TA, Fuchs AF (2007) Contribution of the frontal eye field to gaze shifts in the head-unrestrained monkey: effects of microstimulation. J Neurophysiol 97:618-634. CrossRef Medline

Knudsen EI (2007) Fundamental components of attention. Annu Rev Neurosci 30:57-78. CrossRef Medline

Komiyama T, Sato TR, O'Connor DH, Zhang YX, Huber D, Hooks BM, Gabitto M, Svoboda K (2010) Learning-related fine-scale specificity imaged in motor cortex circuits of behaving mice. Nature 464:1182-1186. CrossRef Medline

Kopec CD, Erlich JC, Brunton BW, Deisseroth K, Brody CD (2015) Cortical and subcortical contributions to short-term memory for orienting movements. Neuron 88:367-377. CrossRef Medline

Krakauer JW, Ghazanfar AA, Gomez-Marin A, MacIver MA, Poeppel D (2017) Neuroscience needs behavior: correcting a reductionist bias. Neuron 93:480-490. CrossRef Medline

Kraskov A, Philipp R, Waldert S, Vigneswaran G, Quallo MM, Lemon RN (2014) Corticospinal mirror neurons. Philos Trans R Soc Lond B Biol Sci 369:20130174. CrossRef Medline

Laubach M, Caetano MS, Narayanan NS (2015) Mistakes were made: neural mechanisms for the adaptive control of action initiation by the medial prefrontal cortex. J Physiol Paris 109:104-117. CrossRef Medline

Laubach M, Wessberg J, Nicolelis MA (2000) Cortical ensemble activity increasingly predicts behaviour outcomes during learning of a motor task. Nature 405:567-571. CrossRef Medline

Lebedev MA, O'Doherty JE, Nicolelis MA (2008) Decoding of temporal intervals from cortical ensemble activity. J Neurophysiol 99:166-186. CrossRef Medline

Lee S, Carvell GE, Simons DJ (2008) Motor modulation of afferent somatosensory circuits. Nat Neurosci 11:1430-1438. CrossRef Medline

Lein ES, Hawrylycz MJ, Ao N, Ayres M, Bensinger A, Bernard A, Boe AF, Boguski MS, Brockway KS, Byrnes EJ, Chen L, Chen L, Chen TM, Chin MC, Chong J, Crook BE, Czaplinska A, Dang CN, Datta S, Dee NR, et al. (2007) Genome-wide atlas of gene expression in the adult mouse brain. Nature 445:168-176. CrossRef Medline

Leinweber M, Ward DR, Sobczak JM, Attinger A, Keller GB (2017) A sensorimotor circuit in mouse cortex for visual flow predictions. Neuron 95:1420-1432.e5. CrossRef Medline

Lemon RN (2008) Descending pathways in motor control. Annu Rev Neurosci 31:195-218. CrossRef Medline

Leonard CM (1969) The prefrontal cortex of the rat: I. cortical projection of the mediodorsal nucleus: II. Efferent connections. Brain Res 12:321-343. CrossRef Medline

Leyton AS, Sherrington CS (1917) Observations on the excitable cortex of the chimpanzee, orang-utan, and gorilla. Q J Exp Physiol 11:135-222. CrossRef

Machens CK, Romo R, Brody CD (2005) Flexible control of mutual inhibition: a neural model of two-interval discrimination. Science 307:11211124. CrossRef Medline

Makino H, Ren C, Liu H, Kim AN, Kondapaneni N, Liu X, Kuzum D, Komiyama T (2017) Transformation of cortex-wide emergent properties during motor learning. Neuron 94:880-890.e8. CrossRef Medline

Manita S, Suzuki T, Homma C, Matsumoto T, Odagawa M, Yamada K, Ota K, Matsubara C, Inutsuka A, Sato M, Ohkura M, Yamanaka A, Yanagawa Y, Nakai J, Hayashi Y, Larkum ME, Murayama M (2015) A top-down cortical circuit for accurate sensory perception. Neuron 86:1304-1316. CrossRef Medline

Mao T, Kusefoglu D, Hooks BM, Huber D, Petreanu L, Svoboda K (2011) Long-range neuronal circuits underlying the interaction between sensory and motor cortex. Neuron 72:111-123. CrossRef Medline

Matyas F, Sreenivasan V, Marbach F, Wacongne C, Barsy B, Mateo C, Aronoff 
R, Petersen CC (2010) Motor control by sensory cortex. Science 330: 1240-1243. CrossRef Medline

Merrikhi Y, Clark K, Albarran E, Parsa M, Zirnsak M, Moore T, Noudoost B (2017) Spatial working memory alters the efficacy of input to visual cortex. Nat Commun 8:15041. CrossRef Medline

Miller EK (2000) The prefrontal cortex and cognitive control. Nat Rev Neurosci 1:59-65. CrossRef Medline

Mimica B, Dunn BA, Tombaz T, Bojja VP, WhitlocknJR (2018) Efficient cortical coding of 3D posture in freely behaving rats. BioRxiv. Retrieved on April 25, 2018. Advance online publication. doi: 10.1101/307785.

Miri A, Warriner CL, Seely JS, Elsayed GF, Cunningham JP, Churchland MM, Jessell TM (2017) Behaviorally selective engagement of short-latency effector pathways by motor cortex. Neuron 95:683-696.e11. CrossRef Medline

Mita A, Mushiake H, Shima K, Matsuzaka Y, Tanji J (2009) Interval time coding by neurons in the presupplementary and supplementary motor areas. Nat Neurosci 12:502-507. CrossRef Medline

Miyashita E, Mori S (1995) The superior colliculus relays signals descending from the vibrissal motor cortex to the facial nerve nucleus in the rat. Neurosci Lett 195:69-71. CrossRef Medline

Moore JD, Deschênes M, Furuta T, Huber D, Smear MC, Demers M, Kleinfeld D (2013) Hierarchy of orofacial rhythms revealed through whisking and breathing. Nature 497:205-210. CrossRef Medline

Moore T, Fallah M (2001) Control of eye movements and spatial attention. Proc Natl Acad Sci U S A 98:1273-1276. CrossRef Medline

Moore T, Armstrong KM (2003) Selective gating of visual signals by microstimulation of frontal cortex. Nature 421:370-373. CrossRef Medline

Morandell K, Huber D (2017) The role of forelimb motor cortex areas in goal directed action in mice. Sci Rep 7:15759. CrossRef Medline

Murakami M, Vicente MI, Costa GM, Mainen ZF (2014) Neural antecedents of self-initiated actions in secondary motor cortex. Nat Neurosci 17:1574-1582. CrossRef Medline

Murakami M, Shteingart H, Loewenstein Y, Mainen ZF (2017) Distinct sources of deterministic and stochastic components of action timing decisions in rodent frontal cortex. Neuron 94:908-919.e7. CrossRef Medline

Murray JD, Bernacchia A, Freedman DJ, Romo R, Wallis JD, Cai X, PadoaSchioppa C, Pasternak T, Seo H, Lee D, Wang XJ (2014) A hierarchy of intrinsic timescales across primate cortex. Nat Neurosci 17:1661-1663. CrossRef Medline

Nachev P, Kennard C, Husain M (2008) Functional role of the supplementary and pre-supplementary motor areas. Nat Rev Neurosci 9:856-869. CrossRef Medline

Nashaat MA, Oraby H, Peña LB, Dominiak S, Larkum ME, Sachdev RN (2017) Pixying behavior: a versatile real-time and post hoc automated optical tracking method for freely moving and head fixed animals. eNeuro 4:ENEURO.0245-16.2017. CrossRef Medline

Neafsey EJ, Sievert C (1982) A second forelimb motor area exists in rat frontal cortex. Brain Res 232:151-156. CrossRef Medline

Neafsey EJ, Bold EL, Haas G, Hurley-Gius KM, Quirk G, Sievert CF, Terreberry RR (1986) The organization of the rat motor cortex: a microstimulation mapping study. Brain Res 396:77-96. CrossRef Medline

Nelson A, Schneider DM, Takatoh J, Sakurai K, Wang F, Mooney R (2013) A circuit for motor cortical modulation of auditory cortical activity. J Neurosci 33:14342-14353. CrossRef Medline

Nelson A, Mooney R (2016) The basal forebrain and motor cortex provide convergent yet distinct movement-related inputs to the auditory cortex. Neuron 90:635-648. CrossRef Medline

Noudoost B, Moore T (2011) Control of visual cortical signals by prefrontal dopamine. Nature 474:372-375. CrossRef Medline

Ocaña FM, Suryanarayana SM, Saitoh K, Kardamakis AA, Capantini L, Robertson B, Grillner S (2015) The lamprey pallium provides a blueprint of the mammalian motor projections from cortex. Curr Biol 25:413-423. CrossRef Medline

O'Connor DH, Clack NG, Huber D, Komiyama T, Myers EW, Svoboda K (2010) Vibrissa-based object localization in head-fixed mice. J Neurosci 30:1947-1967. CrossRef Medline

Ohno S, Kuramoto E, Furuta T, Hioki H, Tanaka YR, Fujiyama F, Sonomura T, Uemura M, Sugiyama K, Kaneko T (2012) A morphological analysis of thalamocortical axon fibers of rat posterior thalamic nuclei: a single neuron tracing study with viral vectors. Cereb Cortex 22:2840-2857. CrossRef Medline
Ölveczky BP (2011) Motoring ahead with rodents. Curr Opin Neurobiol 21:571-578. CrossRef Medline

Omrani M, Kaufman MT, Hatsopoulos NG, Cheney PD (2017) Perspectives on classical controversies about the motor cortex. J Neurophysiol 118:1828-1848. CrossRef Medline

Paxinos G, Watson C (1982) The rat brain in stereotaxic coordinates. Cambridge, MA: Academic.

Penfield W, Boldrey E (1937) Somatic motor and sensory representation in the cerebral cortex of man as studied by electrical stimulation. Brain 60:389-443. CrossRef

Peters AJ, Chen SX, Komiyama T (2014) Emergence of reproducible spatiotemporal activity during motor learning. Nature 510:263-267. CrossRef Medline

Peters AJ, Lee J, Hedrick NG, O’Neil K, Komiyama T (2017a) Reorganization of corticospinal output during motor learning. Nat Neurosci 20: 1133-1141. CrossRef Medline

Peters AJ, Liu H, Komiyama T (2017b) Learning in the rodent motor cortex. Annu Rev Neurosci 40:77-97. CrossRef Medline

Petreanu L, Gutnisky DA, Huber D, Xu NL, O'Connor DH, Tian L, Looger L, Svoboda K (2012) Activity in motor-sensory projections reveals distributed coding in somatosensation. Nature 489:299-303. CrossRef Medline

Piet AT, Erlich JC, Kopec CD, Brody CD (2017) Rat prefrontal cortex inactivations during decision making are explained by bistable attractor dynamics. Neural Comput 29:2861-2886. CrossRef Medline

Prescott TJ, Diamond ME, Wing AM (2011) Active touch sensing. Philos Trans R Soc Lond B Biol Sci 366:2989-2995. CrossRef Medline

Ratcliff R (1978) A theory of memory retrieval. Psychol Rev 85:59-108. CrossRef

Reep RL, Corwin JV, Hashimoto A, Watson RT (1987) Efferent connections of the rostral portion of medial agranular cortex in rats. Brain Res Bull 19:203-221. CrossRef Medline

Reep RL, Corwin JV, Cheatwood JL, Van Vleet TM, Heilman KM, Watson RT (2004) A rodent model for investigating the neurobiology of contralateral neglect. Cogn Behav Neurol 17:191-194. Medline

Remington ED, Narain D, Hosseini EA, Jazayeri M (2018) Flexible sensorimotor computations through rapid reconfiguration of cortical dynamics. Neuron 98:1005-1019.e5. CrossRef Medline

Rigosa J, Lucantonio A, Noselli G, Fassihi A, Zorzin E, Manzino F, Pulecchi F, Diamond ME (2017) Dye-enhanced visualization of rat whiskers for behavioral studies. eLife 6:e25290. CrossRef Medline

Rouiller EM, Moret V, Liang F (1993) Comparison of the connectional properties of the two forelimb areas of the rat sensorimotor cortex: support for the presence of a premotor or supplementary motor cortical area. Somatosens Mot Res 10:269-289. CrossRef Medline

Sachdev RN, Sato T, Ebner FF (2002) Divergent movement of adjacent whiskers. J Neurophysiol 87:1440-1448. CrossRef Medline

Saiki A, Kimura R, Samura T, Fujiwara-Tsukamoto Y, Sakai Y, Isomura Y (2014) Different modulation of common motor information in rat primary and secondary motor cortices. PLoS One 9:e98662. CrossRef Medline

Saiki A, Sakai Y, Fukabori R, Soma S, Yoshida J, Kawabata M, Yawo H, Kobayashi K, Kimura M, Isomura Y (2018) In vivo spiking dynamics of intra- and extratelencephalic projection neurons in rat motor cortex. Cereb Cortex 28:1024-1038. CrossRef Medline

Schall JD, Stuphorn V, Brown JW (2002) Monitoring and control of action by the frontal lobes. Neuron 36:309-322. CrossRef Medline

Schiemann J, Puggioni P, Dacre J, Pelko M, Domanski A, van Rossum MC, Duguid I (2015) Cellular mechanisms underlying behavioral statedependent bidirectional modulation of motor cortex output. Cell Rep 11:1319-1330. CrossRef Medline

Schneider DM, Mooney R (2015) Motor-related signals in the auditory system for listening and learning. Curr Opin Neurobiol 33:78-84. CrossRef Medline

Schneider DM, Nelson A, Mooney R (2014) A synaptic and circuit basis for corollary discharge in the auditory cortex. Nature 513:189-194. CrossRef Medline

Scott BB, Constantinople CM, Akrami A, Hanks TD, Brody CD, Tank DW (2017) Fronto-parietal cortical circuits encode accumulated evidence with a diversity of timescales. Neuron 95:385-398.e5. CrossRef Medline

Seabrook TA, Burbridge TJ, Crair MC, Huberman AD (2017) Architecture, function, and assembly of the mouse visual system. Annu Rev Neurosci 40:499-538. CrossRef Medline 
Shadlen MN, Newsome WT (1996) Motion perception: seeing and deciding. Proc Natl Acad Sci U S A 93:628-633. CrossRef Medline

Shadmehr R (2017) Distinct neural circuits for control of movement vs. holding still. J Neurophysiol 117:1431-1460. CrossRef Medline

Shenoy KV, Sahani M, Churchland MM (2013) Cortical control of arm movements: a dynamical systems perspective. Annu Rev Neurosci 36: 337-359. CrossRef Medline

Siniscalchi MJ, Phoumthipphavong V, Ali F, Lozano M, Kwan AC (2016) Fast and slow transitions in frontal ensemble activity during flexible sensorimotor behavior. Nat Neurosci 19:1234-1242. CrossRef Medline

Sinnamon HM, Galer BS (1984) Head movements elicited by electrical stimulation of the anteromedial cortex of the rat. Physiol Behav 33:185190. CrossRef Medline

Smith JB, Alloway KD (2013) Rat whisker motor cortex is subdivided into sensory-input and motor-output areas. Front Neural Circuits 7:4. CrossRef Medline

Soma S, Saiki A, Yoshida J, Ríos A, Kawabata M, Sakai Y, Isomura Y (2017) Distinct laterality in forelimb-movement representations of rat primary and secondary motor cortical neurons with intratelencephalic and pyramidal tract projections. J Neurosci 37:10904-10916. CrossRef Medline

Sommer MA, Tehovnik EJ (1997) Reversible inactivation of macaque frontal eye field. Exp Brain Res 116:229-249. CrossRef Medline

Squire RF, Noudoost B, Schafer RJ, Moore T (2013) Prefrontal contributions to visual selective attention. Annu Rev Neurosci 36:451-466. CrossRef Medline

Sreenivasan V, Karmakar K, Rijli FM, Petersen CC (2015) Parallel pathways from motor and somatosensory cortex for controlling whisker movements in mice. Eur J Neurosci 41:354-367. CrossRef Medline

Sreenivasan V, Esmaeili V, Kiritani T, Galan K, Crochet S, Petersen CCH (2016) Movement initiation signals in mouse whisker motor cortex. Neuron 92:1368-1382. CrossRef Medline

Stuphorn V, Brown JW, Schall JD (2010) Role of supplementary eye field in saccade initiation: executive, not direct, control. J Neurophysiol 103:801816. CrossRef Medline

Svoboda K, Li N (2018) Neural mechanisms of movement planning: motor cortex and beyond. Curr Opin Neurobiol 49:33-41. CrossRef Medline

Tandon S, Kambi N, Jain N (2008) Overlapping representations of the neck and whiskers in the rat motor cortex revealed by mapping at different anaesthetic depths. Eur J Neurosci 27:228-237. CrossRef Medline

Tanji J, Evarts EV (1976) Anticipatory activity of motor cortex neurons in relation to direction of an intended movement. J Neurophysiol 39:10621068. CrossRef Medline

Tark KJ, Curtis CE (2009) Persistent neural activity in the human frontal cortex when maintaining space that is off the map. Nat Neurosci 12:14631468. CrossRef Medline

Teichert T, Yu D, Ferrera VP (2014) Performance monitoring in monkey frontal eye field. J Neurosci 34:1657-1671. CrossRef Medline

Tennant KA, Adkins DL, Donlan NA, Asay AL, Thomas N, Kleim JA, Jones TA (2011) The organization of the forelimb representation of the C57BL/6 mouse motor cortex as defined by intracortical microstimulation and cytoarchitecture. Cereb Cortex 21:865-876. CrossRef Medline

Thura D, Cisek P (2014) Deliberation and commitment in the premotor and primary motor cortex during dynamic decision making. Neuron 81 : 1401-1416. CrossRef Medline

Tkach D, Reimer J, Hatsopoulos NG (2007) Congruent activity during action and action observation in motor cortex. J Neurosci 27:13241-13250. CrossRef Medline

Towal RB, Hartmann MJ (2006) Right-left asymmetries in the whisking behavior of rats anticipate head movements. J Neurosci 26:8838-8846. CrossRef Medline

Vigneswaran G, Philipp R, Lemon RN, Kraskov A (2013) M1 corticospinal mirror neurons and their role in movement suppression during action observation. Curr Biol 23:236-243. CrossRef Medline

Voigts J, Herman DH, Celikel T (2015) Tactile object localization by anticipatory whisker motion. J Neurophysiol 113:620-632. CrossRef Medline

Wang X, Liu Y, Li X, Zhang Z, Yang H, Zhang Y, Williams PR, Alwahab NSA, Kapur K, Yu B, Zhang Y, Chen M, Ding H, Gerfen CR, Wang KH, He Z (2017) Deconstruction of corticospinal circuits for goal-directed motor skills. Cell 171:440-455.e14. CrossRef Medline

Wardak C (2011) The role of the supplementary motor area in inhibitory control in monkeys and humans. J Neurosci 31:5181-5183. CrossRef

Welker WI (1964) Analysis of sniffing of the albino rat. Behaviour 22:223244. CrossRef

Whissell PD, Tohyama S, Martin LJ (2016) The use of DREADDs to deconstruct behavior. Front Genet 7:70. CrossRef Medline

Wimmer K, Nykamp DQ, Constantinidis C, Compte A (2014) Bump attractor dynamics in prefrontal cortex explains behavioral precision in spatial working memory. Nat Neurosci 17:431-439. CrossRef Medline

Winkowski DE, Knudsen EI (2006) Top-down gain control of the auditory space map by gaze control circuitry in the barn owl. Nature 439:336-339. CrossRef Medline

Witten IB, Steinberg EE, Lee SY, Davidson TJ, Zalocusky KA, Brodsky M, Yizhar O, Cho SL, Gong S, Ramakrishnan C, Stuber GD, Tye KM, Janak PH, Deisseroth K (2011) Recombinase-driver rat lines: tools, techniques, and optogenetic application to dopamine-mediated reinforcement. Neuron 72:721-733. CrossRef Medline

Wolfe J, Mende C, Brecht M (2011) Social facial touch in rats. Behav Neurosci 125:900-910. CrossRef Medline

Wolff SB, Ölveczky BP (2018) The promise and perils of causal circuit manipulations. Curr Opin Neurobiol 49:84-94. CrossRef Medline

Wolpert DM, Landy MS (2012) Motor control is decision-making. Curr Opin Neurobiol 22:996-1003. CrossRef Medline

Wong KF, Wang XJ (2006) A recurrent network mechanism of time integration in perceptual decisions. J Neurosci 26:1314-1328. CrossRef Medline

Yang W, Yuste R (2017) In vivo imaging of neural activity. Nat Methods 14:349-359. CrossRef Medline

Yartsev MM, Hanks TD, Yoon AM, Brody CD (2018) Causal contribution and dynamical encoding in the striatum during evidence accumulation. eLife 7:e34929. CrossRef Medline

Yilmaz M, Meister M (2013) Rapid innate defensive responses of mice to looming visual stimuli. Curr Biol 23:2011-2015. CrossRef Medline

Zagha E, Casale AE, Sachdev RN, McGinley MJ, McCormick DA (2013) Motor cortex feedback influences sensory processing by modulating network state. Neuron 79:567-578. CrossRef Medline

Zagha E, Ge X, McCormick DA (2015) Competing neural ensembles in motor cortex gate goal-directed motor output. Neuron 88:565-577. CrossRef Medline

Zhang S, Xu M, Kamigaki T, Hoang Do JP, Chang WC, Jenvay S, Miyamichi K, Luo L, Dan Y (2014) Long-range and local circuits for top-down modulation of visual cortex processing. Science 345:660-665. CrossRef Medline

Zilles, K., and Wree, A (1995) Cortex: areal and laminar structure. In: The rat nervous system (Paxinos G, ed.), pp 649-685. San Diego: Academic.

Zingg B, Hintiryan H, Gou L, Song MY, Bay M, Bienkowski MS, Foster NN, Yamashita S, Bowman I, Toga AW, Dong HW (2014) Neural networks of the mouse neocortex. Cell 156:1096-1111. CrossRef Medline

Zuo Y, Perkon I, Diamond ME (2011) Whisking and whisker kinematics during a texture classification task. Philos Trans R Soc Lond B Biol Sci 366:3058-3069. CrossRef Medline 